\title{
Recombinant Expression and Enzyme Activity of Chymotrypsin-like Pro- tease from Black Soldier Fly, Hermetia illucens (Diptera: Stratiomyidae)
}

\author{
Kwan Ho Park*, Young Cheol Choi, Sung Hee Nam, Won Tae Kim, A Young Kim, and Sin Young Kim \\ National Academy of Agricultural Science, RDA, Suwon 441-100, Republic of Korea
}

(Received 8 November 2012; Accepted 2 January 2013)

\begin{abstract}
Chymotrypsin serine protease is one of the main digestive proteases in the midgut of and is involved in various essential processes. In a previous study, a gene encoding a chymotrypsin-like protease, Hi-SP1, was cloned from the larvae of Hermetia illucens and characterized. In this study, we produced the recombinant chymotrypsin-like protease Hi-SP1 in Escherichia coli cells. The molecular weight of the recombinant Hi-SP1 was estimated to be approximately 26 kDa by sodium dodecyl sulfate-polyacrylamide gel electrophoresis and Western-blotting. Chymotrypsin activity was detected when AAPF was used as the substrate. Examination of the effects of temperature and $\mathrm{pH}$ revealed that the proteolytic activity of recombinant $\mathrm{Hi}-\mathrm{SP} 1$ decreased markedly at temperatures above $30^{\circ} \mathrm{C}$, and the optimum $\mathrm{pH}$ was found to be 10.0 .
\end{abstract}

Key words: Hermitia illucens, Chymotrypsin-like protease, Recombinant protease

\section{Introduction}

Chymotrypsin is a serine protease that has been extensively studied both structurally and functionally (Blow, 1971). It specifically cleaves peptide bonds on the carboxyl side of phenylalanine, tyrosine, and tryptophan residues. It is also known to play an important role in protein digestion (Balti et al., 2012). Much research has focused on midgut enzymes of insects, and special atten-

\footnotetext{
*To whom the correspondence addressed

Department of Agricultural Biology, National Academy of Agricultural Science, RDA, Suwon 441-100, Republic of Korea.

Tel: +82-31-290-8575; Fax: +82-31-290-8543;

E-mail: nicegano@korea.kr

http://dx.doi.org/10.7852/ijie.2012.25.2.181
}

tion has been directed toward trypsin and chymotrypsin, which belong to the trypsin subfamily (Rawlings and Barrett, 1994). Trypsin and chymotrypsin are the major proteases found in most insect species, which take part in a number of physiological processes such as coagulation, immunity, fibrinolysis, embryonic development, and digestion (Noriega and Wells, 1999). As in mammals, insect chymotrypsins are SPs that cleave substrates at the carboxyl termini of hydrophobic amino acids such as tyrosine, tryptophan, leucine, or phenylalanine (Mazumdar-Leighton and Broadway, 2001). In insects, the most abundant and best studied group of SPs contains those expressed in the larval midgut, which are thought to be involved in the digestion of dietary protein (Herrero et al., 2005). The black soldier fly (BSF), Hermetia illucens, belongs to the polyphagous insect group (Kim et al., 2011). These flies can devour large amounts of garbage and food scraps in just a few hours, converting the waste into organic material that can be used as fertilizer (Diener et al., 2009). BSF is economically important as animal feed. The prepupae and larvae have an estimated value comparable to fishmeal can be used as specialty feed for a variety of pets, including reptiles; however, pretreatment with BSF digestive enzymes is required for their use as animal feed. In a previous study, we cloned and characterized a trypsin- and a chymotrypsin-like protease gene from BSF. The full-length cDNA of $H$. illucens chymotrypsin-like protease (HiSP1) is $895 \mathrm{bp}$ with an open reading frame of $804 \mathrm{bp}$. The Hi-SP1 cDNA encodes a polypeptide of 267 amino acids (aa), consisting of a 16-aa signal peptide and a trypsin domain (34-263 aa) (Kim et al., 2011).

To the best of our knowledge, no recombinant protease of BSF has previously been purified and characterized. Here, we report the production and purification of Hi-SP1 from BSF. The recombinant protease was characterized with respect to its biochemical properties. 


\section{Materials and Methods}

Expression and purification of recombinant chymotrypsinlike Hi-SP1 in E. coli

To express Hi-SP1 in E. coli cells (Rosetta (DE3) pLysS), Hi-SP1 cDNA was cloned into the pET-22b vector. The encoding DNA fragment was confirmed by sequencing. The Rosetta (DE3) pLysS were maintained on Luria-Bertani (LB) medium supplemented with $50 \mathrm{mg} / \mathrm{ml}$ ampicillin at $37^{\circ} \mathrm{C}$ with agitation. A $25 \mu \mathrm{l}$ aliquot of the overnight culture was added to $25 \mathrm{ml} \mathrm{LB}$ medium containing $50 \mathrm{mg} / \mathrm{ml}$ of ampicillin. Protein expression was induced by adding $1 \mathrm{mM}$ isopropylthio-b-galactoside (IPTG) for overnight at $37^{\circ} \mathrm{C}$, when the cells reached the exponential growth [optical density (OD)600 0.6]. The E. coli cells were harvested by centrifugation $\left(3000 \mathrm{rpm}, 10 \mathrm{~min}, 4^{\circ} \mathrm{C}\right.$ ) and lysed by sonication in $50 \mathrm{ml}$ lysis buffer $(50 \mathrm{mM}$ $\mathrm{NaH}_{2} \mathrm{PO}_{4}, 300 \mathrm{mM} \mathrm{NaCl}, 10 \mathrm{mM}$ imidazole). The sonicated cells were shaking with lysozyme $(0.1 \mathrm{mg} / \mathrm{ml})$ and $0.1 \%$ triton $\mathrm{X}-100$ in ice for $\mathrm{Ihr}$. After centrifugation (20000 rpm, $15 \mathrm{~min}$ ), the supernatant were applied to $5 \mathrm{ml}$ of beads into a Poly-Prep chromatography column (BioRad Laboratories, Hercules, CA, USA) at $4^{\circ} \mathrm{C}$. Proteins were eluted with $3 \mathrm{ml}$ of $500 \mathrm{mM}$ imidazole elution buffer (50 mM NaH $2 \mathrm{PO}_{4}, 300 \mathrm{mM} \mathrm{NaCl}, 250 \mathrm{mM}$ imidazole).

\section{SDS-PAGE and Western-blot analysis}

To characterize the recombinant proteases produced by the transformants of pET-22b, SDS-PAGE was used for analysis. For SDS-PAGE analysis, the concentration of stacking gel was $7 \%$ and the concentration of separating gel was $12 \%$. The protein bands were made visualised by staining them with Coomassie Brilliant Blue. Western-blot analysis was used to confirm the expressed recombinant Hi-SP1. Following electrophoresis, the proteins transferred to nitrocellulose transfer membranes (Schleicher \& Schuell, Germany). After blotting, the membrane was blocked by incubation in 5\% skimmilk blocking solution, incubated with His-probe antibody $(1: 10000 \mathrm{v} / \mathrm{v})$ at room temperature for $3 \mathrm{hr}$ and washed in TBS-T $(10 \mathrm{mM}$ Tris- $\mathrm{HCl}, \mathrm{pH} 8.0$, $100 \mathrm{mM} \mathrm{NaCl}, 0.05 \%$ (v/v) Tween-20). The membrane was conjugated with Goat antimouse IgG-HRP (1:10000 v/v) for $1 \mathrm{hr}$ as secondary antibody. After repeated washing, the band visualization was achieved via chemiluminescence.

\section{Determination of protease activity and enzyme assay}

Recombinant Hi-SP1 activity was measured by zymography. Casein (Novex 12\% Zymogram, Casein, Invitrogen) zymography was performed as manufacturer's instructions. Briefly, recombinant Hi-SP1 was mixed with Tris glycine SDS sample buffer and ran for $90 \mathrm{~min}$ at $125 \mathrm{~V}$ at $4^{\circ} \mathrm{C}$. After electrophoresis, the gels were incubated in rena- turing buffer for $30 \mathrm{~min}$ at room temperature, followed with incubation in developing buffer at $37^{\circ} \mathrm{C}$ overnight. Finally, the gel was stained with $0.1 \%$ Coomassie brilliant blue staining solution and destained in destaining solution containing 10\% methanol and 5\% acetic acid. Lytic band visualized by placing the gels on a view box were then photographed. Chymotrypsin activity was measured using the synthetic substrate N-succinyl-ala-ala-pro-phe-nitroanilide (AAPF). Sample contained $100 \mu 1$ of $50 \mathrm{mM}$ Tris$\mathrm{HCl}$ buffer, pH 7.9 and $10 \mu \mathrm{l}$ of substrate (200 mM AAPF) dissolved in DMSO. Reactions were initiated by the addition of $10 \mu 1$ of recombinant Hi-SP1, and carried out at $39^{\circ} \mathrm{C}$ for 20 to $120 \mathrm{~min}$. The rate of formation of the hydrolysis product was measured at $410 \mathrm{~nm}$ in a spectrophotometer. Separate control with no recombinant Hi-SP1 was carried for substrate and experimental values were corrected for background hydrolysis of the substrate. Each enzyme reaction was repeated in triplicate.

\section{Effects of temperature and $\mathrm{pH}$ on the activity and stability of the recombinant Hi-SP1}

The effect of temperature on the activity of recombinant Hi-SP1 was determined by incubating the recombinant enzyme between 10 and $90^{\circ} \mathrm{C}$ using the standard assay conditions used for the determination of the protease activity. The reaction mixture, composed of $1 \mathrm{~mL}$ of azocasein $(2 \mathrm{mg} / \mathrm{mL}$ in $0.2 \mathrm{M}$ Tris- $\mathrm{HCl}$ buffer, $\mathrm{pH} 7.8)$ and $20 \mu \mathrm{L}$ of recombinant $\mathrm{Hi}-\mathrm{SP} 1(640 \mu \mathrm{g} / \mathrm{mL})$, was incubated at $37^{\circ} \mathrm{C}$. After $1 \mathrm{hr}, 0.25 \mathrm{ml}$ of the mixture was transferred to a $1.5 \mathrm{~mL}$ tube containing $1 \mathrm{~mL}$ of $5 \%$ (w/ v) trichloroacetic acid and was mixed well. The tubes were then centrifuged at $11,000 \mathrm{~g}$ for $5 \mathrm{~min}$ and the absorbance of the supernatant was measured at $450 \mathrm{~nm}$. In a similar way, the effect of $\mathrm{pH}$ values on the recombinant Hi-SP1 was investigated by incubating the recombinant enzyme at different $\mathrm{pH}$ values (2.0-12.0). In various buffers with $\mathrm{pH}$ ranges from 2 to $12 \mathrm{Hi}-\mathrm{SP} 1$ of $20 \mu \mathrm{l}(0.1 \mu \mathrm{g} / \mu \mathrm{l})$ was added to $80 \mu \mathrm{l}$ of $50 \mathrm{mM}$ Tris- $\mathrm{HCl}$ buffer for $\mathrm{pH} 2-8$ and $50 \mathrm{mM}$ glycine- $\mathrm{NaOH}$ buffer for $\mathrm{pH} 10-12$, respectively. After incubating for $1 \mathrm{hr}$ at $37^{\circ} \mathrm{C}$, the remaining protease activity $(\%)$ was measured using azocasein as a substrate. The relative activity at different $\mathrm{pH}$ values and temperatures was calculated when the recombinant Hi-SP1 activity obtained at the $\mathrm{pH}$ of 10.0 and the temperature of $10^{\circ} \mathrm{C}$ was used as a reference (relative activity was $100 \%$ ).

\section{Results and Discussion}

Expression and purification of recombinant Hi-SP1 In order to obtain recombinant Hi-SP1 for further func- 


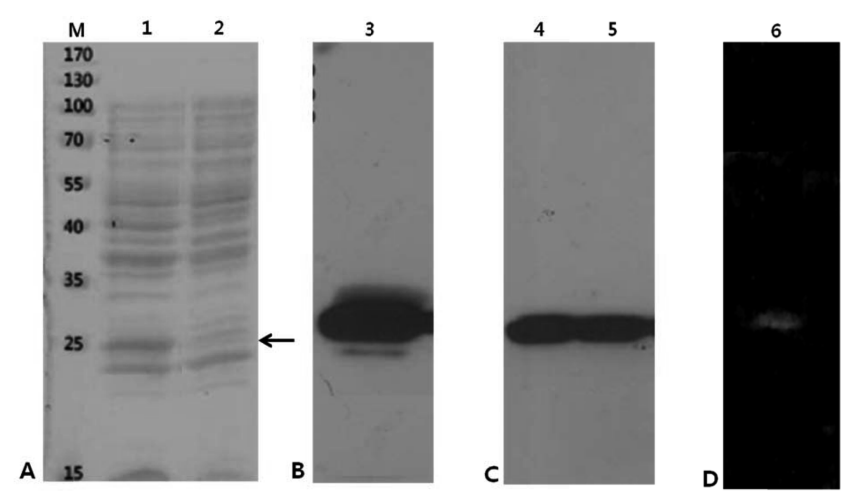

Fig. 1. SDS-PAGE analysis of expression of Hi-SP1 in E. coli: (A) Lane M, protein molecular weight markers; Lane 1, total protein extracts from IPTG-induced transformants harboring the plasmid pET22b; Lane 2, protein extracts from E. coli cell containing empty vector pET22b; (B) Lane 3, Western-blotting confirmation of recombinant protein with His-probe antibody and Goat antimouse IgG-HRP as second antibody; (C) Lane 4 and 5, protein extracts from IPTG -induced transformants harboring the plasmid pET22b; (D) Lane 6, zymogram of the purified recombinant Hi-SP1 chymotrypsin-like protease.

tional studies, we selected and E. coli expression system. Recombinant protein was expressed by inducing E. coli (Rosetta (DE3) pLysS) with $1 \mathrm{mM}$ IPTG. The expected molecular mass of recombinant Hi-SP1 was approximately $25 \mathrm{kDa}$. Recombinant Hi-SP1 was purified using an Ni-NTA purification system (MCLAB, USA). Using a rather complex insect cell system, we analyzed the activity of purified Hi-SP1 toward the substrate azocasein and specific substrate AAPF. The system used here may well be applicable to other dipteran chymotrypsins, although the expression of some enzymes may be difficult to obtain a high yield without damage to the expression system. Trypsin and chymotrypsin are the major proteases in most insect species (Noriega and Wells, 1999). The estimated molecular mass of recombinant Hi-SP1, 25kDa, was similar to other mammalian and insect chymotrypsin proteinases (Gráf et al., 1998; Lee and Anstee, 1995; Terra and Ferreira, 1994). As seen in Fig. 1A, purified Hi-SP1 protein showed an estimated mobility of approximately $26 \mathrm{kDa}$, which is close to the molecular weight $(25 \mathrm{kDa})$ of the mature Hi-SP1 protein, as predicted from the gene sequence (including the $6 \times$ His-tag). The estimated yield of purified recombinant Hi-SP1 was approximately $0.64 \mathrm{mg} / \mathrm{l}$ of medium. By Western-blot analysis of the proteins with a monoclonal antibody to the His-tag, we identified a specific protein band of the same size as that obtained by sodium dodecyl sulfate-polyacrylamide gel electrophoresis (SDS-PAGE; Fig. 1B, 1C), indicating that the recombi-

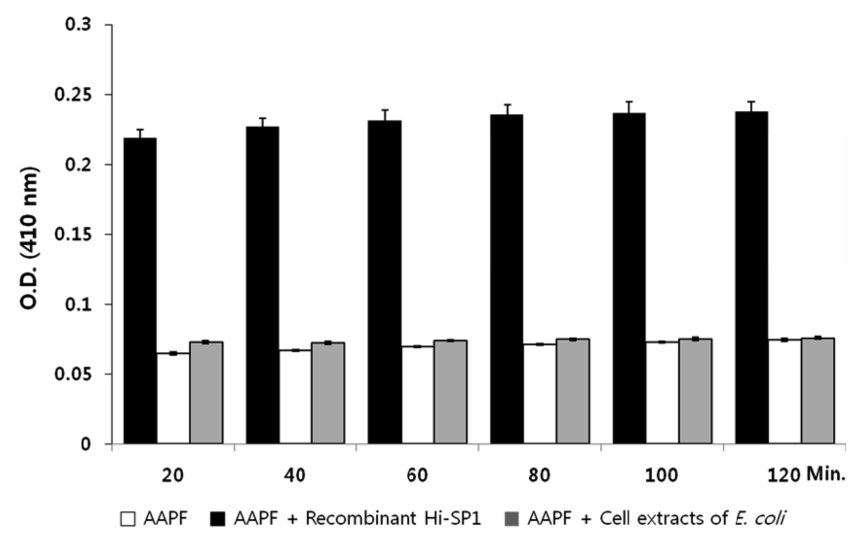

Fig. 2. Chymotrypsin activity measured in purified recombinant Hi-SP1. Activity measured using the AAPF substrate for chymotrypsin-like activity.

nant protein was fused with the His-tag. The recombinant proteases were purified by Ni-NTA affinity chromatography and were subjected to SDS-PAGE analysis. These results indicate a specific band with a molecular weight of approximately $26 \mathrm{kDa}$ (Fig. 1B), suggesting that the purified protein was the recombinant Hi-SP1. Purified Hi-SP1 was used for analyzing the enzyme activity by the casein zymography assay using the specific substrate AAPF, and the enzyme activity was detected.

\section{Determination of protease activity}

Zymography is a sensitive and rapid assay method for analyzing protease activity, and the proteolytic activity of the recombinant Hi-SP1 protein was confirmed by this method. As shown in Fig. 1D, we observed a single clear hydrolyzed casein indicating homogeneity of the purified chymotrypsin. Chymotrypsin activity could be detected when AAPF was used as the substrate. The observed activity detected in a control experiment was less in the absence of the recombinant Hi-SP1 protein (Fig. 2).

\section{Effects of temperature and $\mathrm{pH}$ on the stability of the recombinant Hi-SP1}

Azocasein was used as the substrate in assays of the effects of temperature and $\mathrm{pH}$ on recombinant Hi-SP1 protease activity.

The results indicate that Hi-SP1 has azocaseinolytic activity within a broad range of $\mathrm{pH}$ values, from acidic to alkaline. The residual activity of recombinant Hi-SP1 was evaluated after heat treatment for $60 \mathrm{~min}$ at various temperatures, and the results are shown in Fig. 3A. Like other enzymes, the recombinant Hi-SP1 showed good stability when pre-incubated at lower temperatures $\left(\leq 10^{\circ} \mathrm{C}\right)$, whereas the total protease activity did not change up to 

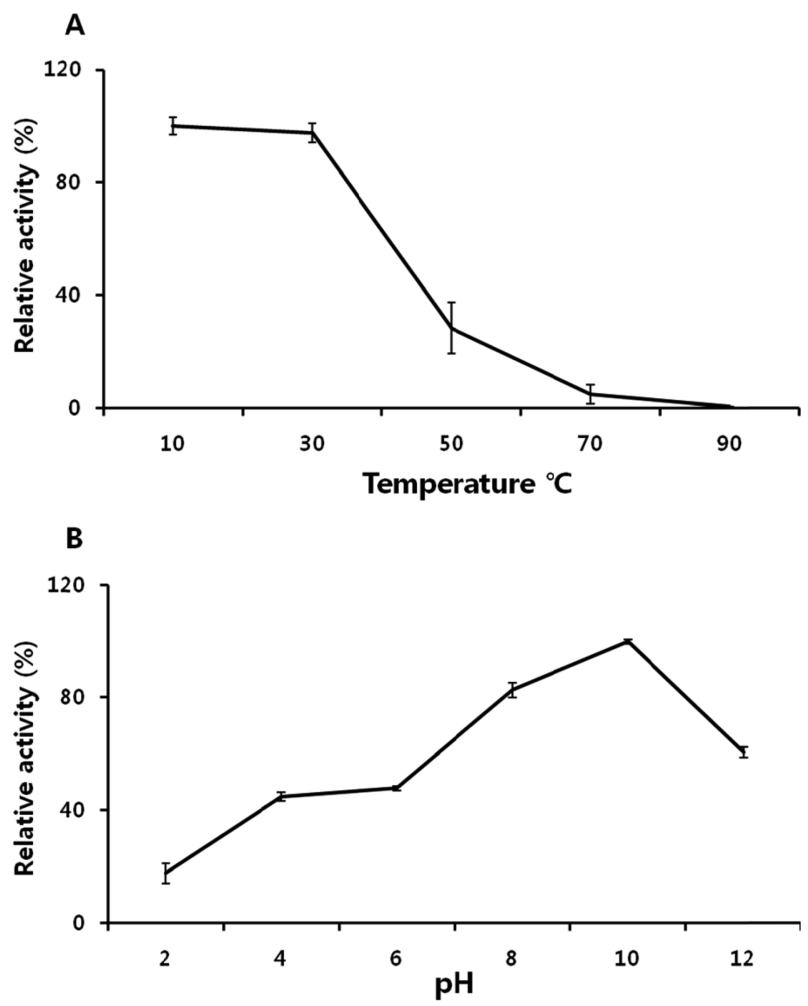

Fig. 3. Effects of temperature (A) and $\mathrm{pH}(\mathrm{B})$ on the activity of the recombinant Hi-SP1 protease assay. The effect of temperature on the stability was examined by pre-incubating the enzyme at different temperatures $\left(10-90^{\circ} \mathrm{C}\right)$ for $1 \mathrm{hr}$ and the effect of $\mathrm{pH}$ on the stability was examined by pre-incubating the enzyme at different $\mathrm{pH}$ values (2-12) for $1 \mathrm{hr}$. Three replicates of each treatment were prepared.

$30^{\circ} \mathrm{C}$. Further increases in temperature altered protease activity, and any further increase in the temperature decreased the enzyme activity; the lowest activity was detected at $90^{\circ} \mathrm{C}$, mainly due to thermal denaturation (Klomklao et al., 2007). As shown in Fig. 3B, when recombinant $\mathrm{Hi}-\mathrm{SP} 1$ was pre-incubated at $\mathrm{pH}$ of values 212, the optimum $\mathrm{pH}$ was found to be 10.0 (Fig. 3B). The total proteolytic activity of the recombinant Hi-SP1 for azocasein hydrolysis increased when the $\mathrm{pH}$ was increased from 6.0 to 10.0 . The relatively low activity at an acidic $\mathrm{pH}$ was probably due to changes in charge distribution and conformation, which prevented the enzyme from proper substrate binding (Simpson and Haard, 1984). Unlike mammalian enzymes, the low stability of the enzyme in buffers with acidic $\mathrm{pH}$ values $(<4.0)$ is typical for insect chymotrypsins (Terra and Ferreira, 1994; Terra et al., 1996). Recombinant Hi-SP1 was active at a broad range of $\mathrm{pH}$, with the maximum activity detected at $\mathrm{pH}$ 10.0. This property of the enzyme is important when considering its industrial applications.

\section{Acknowledgements}

We are grateful to Kyung Su Ahn, In Im Kim and Sung Mook Jo for their valuable help in rearing the black soldier fly. This work supported by a grant from the National Academy of Agricultural Science, Rural Development Administration, Republic of Korea (PJ0068932012).

\section{References}

Balti R, Bougherra F, Bougatef A (2012) Chymotrypsin from the hepatopancreas of cuttlefish (Sepia officinalis) with high activity in the hydrolysis of long chain peptide substrates: Purification and biochemical characterisation. Food Chem 130, 475-484.

Blow DM (1971) The structure of chymotrypsin, Vol. 3. New York: Academic Press.

Bondari K, Sheppard DC (1981) Soldier fly larvae as feed in commercial fish production. Aquaculture 24, 103-109.

Diener S, Zurbrugg C, Tockner K (2009) Conversion of organic material by black soldier fly larvae: establishing optimal feeding rates. Waste Manage Res 27, 603-610.

Gráf L, Szilágyi L, Venekei I (1998) Chymotrypsin. San Diego, Academic Press

Herrero S, Combes E, Van Oers MM, Vlak JM, de Maagd RA, Beekwilder, J (2005) Identification and recombinant expression of a novel chymotrypsin from Spodoptera exigua. Insect Biochem Molec 35, 1073-1082.

James MT (1935) The genus Hermetia in the United States (Diptera: Stratiomyidae). Bull Brooklyn Entomol Soc 30, 165-170.

Kim JG, Choi YC, Choi JY, Kim WT, Jeong GS, Park KH, Hwang SJ (2008) Ecology of the black soldier fly, Hermetia illucens (Diptera: Stratmyidae) in Korea. Kor J Appl Entomol 47, 337-343.

Kim JI (1997) Newly recording two exotic insects species from Korea. J Kor Biota 2, 223-225.

Kim W, Bae S, Kim A (2011) Characterization of the molecular features and expression patterns of two serine proteases in Hermetia illucens (Diptera: Stratiomyidae) larvae. Bmb Rep 44, 387-392.

Klomklao S, Benjakul S, Visessanguan W, Kishimura H, Simpson BK (2007) Trypsin from the pyloric caeca of bluefish (Pomatomus saltatrix). Comp Biochem Phys B 148, 382-389

Lee MJ, Anstee JH (1995) Endoproteases from the midgut of larval Spodoptera littoralis include a chymotrypsin-like enzyme with an extended binding-site. Insect Biochem Molec 25, 49-61.

Lord WD, Goff ML, Adkins TR, Haskell NH (1994) The black soldier fly Hermetia illucens (Diptera: Stratiomyidae) as a potential measure of human postmortem interval: observations and case histories. J Forensic Sci 39, 215-222.

Mazumdar-Leighton S, Broadway RM (2001) Identification of six chymotrypsin cDNAs from larval midguts of Helicov- 
erpa zea and Agrotis ipsilon feeding on the soybean (Kunitz) trypsin inhibitor. Insect Biochem Molec 31, 633-644.

McCallan E (1974) Hermetia illucens (L.) (Diptera: Stratiomyidae), a cosmopolitan American species long established in Australia and New Zealand. Entomol Mo Mag 109, 232234.

Newton GL, Booram CV, Barker RW, Hale OM (1977) Dried Hermetia illucens larvae meal as a supplement for swine. J Anim Sci 44, 395-400.

Noriega FG, Wells MA (1999) A molecular view of trypsin synthesis in the midgut of Aedes aegypti. J Insect Physiol 45, 613-620.

Rawlings ND, Barrett AJ (1994) Families of Serine Peptidases. Proteolytic Enzymes: Serine and Cysteine Peptidases 244, 19-61.

Sheppard DC, Newton GL, Thompson SA (1994) A value added manure management system using the black soldier fly. Bio resource Tech 50, 275-279.
Simpson, BK and Haard, NF (1984) Trypsin from Greenland cod, Gadus ogac. Isolation and comparative properties. Comp Biochem Physiol 79.

Terra WR, Ferreira C (1994) Insect Digestive Enzymes - Properties, Compartmentalization and Function. Comp Biochem Phys B 109, 1-62.

Terra WR, Ferreira C, Jordao BP, Dillon RJ (1996) Digestive enzymes. London: Chapman and Hall.

Tomberlin JK, Sheppard DC (2002) Factors influencing mating and oviposition of black soldier flies (Diptera: Stratiomyidae) in a colony. J Entomol Sci 37, 345-352.

Tomberlin JK, Sheppard DC, Joyce JA (2005) Black soldier fly (Diptera: Stratiomyidae) colonization of pig carrion in South Georgia. J Forensic Sci 50, 152-153.

Tomberlin JK, Peter HA, Heidi MM (2009) Black Development of the black soldier fly (Diptera: Stratiomyidae) in relation to temperature. Environ Entomol 38, 930-934. 